\title{
1. Introduction: how far to ecological law? A look at mining through the lens of ecological law
}

Ecological law is a legal paradigm that is emerging in response to the current ecological crisis. This book explores the main challenges and opportunities for a shift to this new paradigm in existing laws, particularly in the context of mining. ${ }^{1}$

The book has three parts. Part I offers a synthesis of the emerging theory of ecological law. It summarizes the main critiques, scientific and economic concepts, legal scholarship, and proposals that contribute to the theory of ecological law. Two short chapters examine the use of the term "ecological law" to name this emerging paradigm, propose a definition, and discuss whether the ecological law paradigm shift is feasible. The final two chapters in this part briefly discuss the relationship and potential synergies of ecological law with Indigenous legal traditions and with green legal theory.

Part II of the book proposes an analytical tool to help improve the understanding of what a shift to ecological law would entail: the lens of ecological law. This lens builds primarily on Geoffrey Garver's proposal of "the rule of ecological law as a legal complement to degrowth economics," on Klaus Bosselmann's concept of ecological justice, and on Cormac Cullinan's manifesto for Earth jurisprudence and wild law. The lens of ecological law consists of three principles of ecological law: ecocentrism, ecological primacy, and ecological justice. ${ }^{2}$

In Part III of the book, three case studies examine the implications for a shift to ecological law by applying the lens of ecological law to three different legal approaches to mining. Mining is a fitting focus for this exercise given the ubiq-

1 This book is adapted from Carla Sbert Carlsson, Mining from the Lens of Ecological Law: Obstacles and Opportunities for Re-formation (Ottawa: University of Ottawa, 2019).

2 A short, early iteration of the lens of ecological law was described and applied in Carla Sbert Carlsson, "Amparos by Indigenous Communities Against Mining Concessions in Mexico: Implications for a Shift to Ecological Law," (2017) X:2 Mexican Law Review 3, online: https://revistas.juridicas.unam.mx/index.php/mexican -law-review/issue/view/573. 
uity of minerals in the lives of practically all humans today, the devastating impact mining usually has on the landscape and neighbouring communities and the nonrenewable nature of minerals.

The first case study queries whether El Salvador's ban on metal mining (the first globally) is a step towards ecological law. In considering mineral extraction proposed in Ontario's Ring of Fire, the second case study searches for elements of ecological law in a legal framework that purportedly ensures the sustainability of mineral extraction in one of the few ecologically intact regions remaining in the world. ${ }^{3}$ Finally, the third case study examines mineral extraction in the context of the rights of Mother Earth and the Andean concept of vivir bien/buen vivir (living well), both recognized in Bolivian law, and considers their significance for ecological law with a particular focus on Bolivia's lithium industrialization project in the Salar de Uyuni.

The book's conclusion provides a preliminary assessment of the lens of ecological law as an analytical tool, and an overview of the key obstacles and opportunities for a shift to ecological law identified through the case studies. It closes with some thoughts on the ecological law transformation of mining and on further research regarding ecological law generally, and concerning mining in an ecologically just society.

Ecological law would demand that mining be carried out without causing serious harm to humans (workers, neighbours, and users/consumers) and other beings, and without diminishing the ecological integrity of the ecosystem in which it takes place. These are major demands that will involve profound changes in the way mining is carried out (scale, timeframes, and technologies) as well as with respect to the reasons why minerals are extracted, how they are traded and the relationships between a mine and its miners, its neighbours, and its ecological context.

This book aims to contribute both to the transformation of law towards ecological law and to the transformation of mining so it may become part of an ecological and convivial society (roughly in the sense proposed by Ivan Illich). These transformations are paths towards the mutually enhancing humanEarth relationship which Thomas Berry argued is forthcoming as part of the evolution of the Universe. They are radical transformations that will most certainly be very difficult to achieve, but that need to be imagined, analyzed, and debated.

3 An abridged version of these two case studies appeared in Carla Sbert, "El Salvador's Mining Ban and Mining in Ontario's Ring of Fire from the Lens of Ecological Law," (2019) 43:3 Vt L Rev 517. 